\title{
Rates and pathways of carbon oxidation in permanently cold Arctic sediments
}

\author{
Joel E. Kostka*, Bo Thamdrup **, Ronnie Nohr Glud ${ }^{* * *}$, Donald E. Canfield ${ }^{* *}$ \\ Max Planck Institute for Marine Microbiology, Celsiusstr. 1, D-28359 Bremen, Germany
}

\begin{abstract}
We report here a comprehensive study of the rates and pathways of carbon mineralization in Arctic sediments. Four sites were studied at 115 to $329 \mathrm{~m}$ water depth in fjords on Svalbard and in coastal Norway. The Svalbard coastal region is characterized by permanently cold bottom water tem-

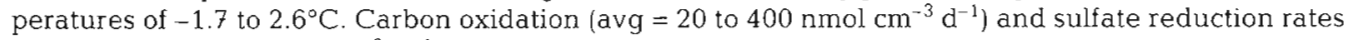
$\left(\right.$ avg $=10$ to $350 \mathrm{nmol} \mathrm{cm} \mathrm{c}^{-3} \mathrm{~d}^{-1}$ ) were measured at high resolution to $10 \mathrm{~cm}$ depth in sediment incubations. The distribution of oxidants available for microbial respiration was determined through porewater and solid phase geochemistry. By comparing the distribution of potential oxidants to the depth-integrated mineralization rates, the importance of various respiratory pathways to the oxidation of organic $C$ could be quantified. Integrated $C$ oxidation rates measured in sediment incubations ( 11 to $24 \mathrm{mmol} \mathrm{m} \mathrm{m}^{-2} \mathrm{~d}^{-1}$ ) were comparable to within a factor of 2 to dissolved inorganic carbon (DIC) fluxes measured in situ using a benthic lander. Sulfate reduction was the dominant microbial respiration pathway (58 to $92 \%$ of total C oxidation) followed by Fe(III) reduction ( 10 to $26 \%$ ), oxygen (5 to $14 \%$ ), and nitrate respiration ( 2 to $3 \%$ ). At sediment depths where sulfate reduction was dominant, $\mathrm{C}$ oxidation equivalents, calculated from independently measured sulfate reduction rates, matched DIC production rates in incubations. Sediment geochemistry revealed that the same vertical sequence of oxidants is reduced/respired in these Arctic sediments as in temperate continental shelf sediments of equivalent water depths. Microbial communities in permanently cold Arctic sediments exhibited mineralization rates and pathways comparable to temperate nearshore environments. This study completely partitioned $\mathrm{C}$ oxidation pathways, showing a predominance of sulfate respiration and a substantial contribution of Fe(III) reduction to organic matter mineralization in Arctic sediments for the first time. Microbial communities in cold sediments exposed to relatively high $\mathrm{C}$ deposition appear to respond to the input or availability of organic matter rather than to temperature.
\end{abstract}

KEY WORDS: Arctic S Sediment - Sulfate reduction - Fe(III) reduction - Organic matter mineralization . Carbon cycle

\section{INTRODUCTION}

Due to the large areal extent of its continental shelves, the biogeochemistry of the Arctic Ocean is largely influenced by processes occurring in its relatively shallow shelf seas (Anderson 1995). Interaction

Present addresses:

- Skidaway Institute of Oceanography, 10 Ocean Science Circle, Savannah, GA 31411, USA

E-mail: joel@skio.peachnet.edu

- Institute of Biology, University of Odense, Campusvej 55, DK-5230 Odense, Denmark

-..Marine Biological Laboratory, University of Copenhagen, Strandpromenaden 5, DK-3000 Helsingør, Denmark between benthic processes on the shelf and nutrient cycling in the Arctic Ocean proper has been demonstrated but is not well understood. For example, benthic-pelagic coupling was indicated by nutrient release and $\mathrm{O}_{2}$ consumption in high salinity bottom water in the Storfjorden, southern Svalbard (Anderson \& Jones 1988, Hulth et al. 1994), and the outflow of this bottom water was traced down the continental slope of the Norwegian Sea to the Fram Strait (Quadfasel et al. 1988). These observations argue for a strong connection between benthic shelf processes and the chemistry of the Arctic Ocean.

Benthic-pelagic coupling has been indicated in Arctic sediments by correlating benthic metabolism and 
standing stocks with overlying water column production (Grebmeier \& McRoy 1989, Grebmeier et al. 1995, Reigstad \& Wassman 1996, Wassman et al. 1996). However, much less data is available on the quantification of benthic processes (rates, pathways) which control nutrient release in Arctic sediments relative to temperate environments. Few studies have measured rates of microbial respiration associated with organic diagenesis or characterized the dominant, operative pathways of respiration (Nedwell et al, 1993, Rysgaard et al. 1996). In addition, fewer studies still have focused on the biogeochemistry of anoxic sediments existing under permanently cold temperatures (Hulth et al. 1996)

Many ecologists have considered, based mainly on water column studies, that microbial communities at high latitudes, though similar in biomass to their temperate counterparts, exhibit low rates of metabolism due to temperature limitation (Pomeroy \& Deibel 1986, Pfannkuche \& Thiele 1987). Pomeroy et al. (1991) postulated, based on rate measurements in the water column and benthos in Newfoundland, that microbial metabolism at cold temperatures was limited by the ability of bacteria to assimilate organic substrates at the low concentrations usually present. However, several studies have challenged this hypothesis. Based on a review of published data, Rivkin et al. (1996) observed that temperature had little effect on bacterial growth rates. Furthermore, high rates of sedimentary $\mathrm{C}$ oxidation and $\mathrm{O}_{2}$ consumption have been measured in cold, polar sediments (Blackburn 1987, Grebmeier \& McRoy 1989, Nedwell et al. 1993, Rysgaard et al. 1996) and in the deep sea (Jahnke \& Jackson 1992). In a study of polar sediments at constant cold temperatures $\left(-1.8\right.$ to $\left.0.5^{\circ} \mathrm{C}\right)$, Nedwell et al. (1993) concluded that seasonal variation in benthic activity was regulated by the input and availability of organic matter and not by water temperature.

Organic matter is oxidized in marine sediments via a complex web of fermentative and respiratory microbial pathways where the oxidation of organic C is balanced by the concommitant reduction of inorganic electron acceptors $\left[\mathrm{O}_{2}, \mathrm{NO}_{3}{ }^{-}, \mathrm{Mn}(\mathrm{IV}), \mathrm{Fe}(\mathrm{III})\right.$ and $\left.\mathrm{SO}_{4}{ }^{2-}\right]$. Many previous studies have explored the relative importance of different $C$ oxidation pathways in temperate environments (Jørgensen 1982, Henrichs \& Reeburgh 1987. Reimers et al. 1992, Canfield et al. 1993a,b, Thamdrup et al. 1994, Hines et al. 1997). Complete characterization of $\mathrm{C}$ oxidation processes has been hampered, however, by our inability to directly measure rates of many of the oxidation pathways. No direct assays are available for quantification of heterotrophic $\mathrm{O}_{2}$ or metal respiration in sediments, for example, and difficulties in constraining the amount of $\mathrm{O}_{2}$ consumed through the reoxidation of respiration products further confounds our analysis of $\mathrm{C}$ oxidation pathways.
New techniques allow the significance of various $\mathrm{C}$ oxidation pathways to be determined in marine sediments (Canfield et al. 1993a,b, Thamdrup \& Canfield 1996), and a similar approach has been applied in freshwater sediments (Roden \& Wetzel 1996). Thus, using a comprehensive approach wherein a range of measurements together constrain the rates, suboxic/ anoxic mineralization processes such as sulfate reduction and metal reduction have been shown to contribute to a larger portion of $\mathrm{C}$ oxidation than was previously perceived (Canfield et al. 1993a, Thamdrup \& Canfield 1996). Conversely, these new studies determined that aerobic respiration accounts for a smaller percentage of organic $\mathrm{C}$ oxidation $(<20 \%$ ) compared to previous estimates in coastal marine sediments (Canfield et al. 1993b). To date, the new comprehensive technique has been applied only in temperate, coastal marine systems with bottom water temperatures of $5^{\circ} \mathrm{C}$ and above.

Cold temperatures are the rule rather than the exception in the world ocean with a majority of the sea bottom exposed to temperatures of $5^{\circ} \mathrm{C}$ or less. These temperatures are below those at which most process studies of $\mathrm{C}$ mineralization have been made. Therefore, the present study was carried out in fjords of Svalbard and coastal Norway, an area where sediments are exposed to relatively high organic $C$ input under exceptionally low temperatures $\left(7\right.$ to $\left.-1.8^{\circ} \mathrm{C}\right)$. Given the paucity of data on Arctic sediments, the primary goal was to characterize the sediment biogeochemistry in detail, especially with regard to organic remineralization. More specifically, the purpose was to use a combination of geochemical methods and direct rate measurements to determine the effect of temperature on the rates and pathways of $C$ oxidation.

\section{METHODS}

Site description. The study was part of a larger expedition which focused on the microbial ecology of cold sediments carried out from 10 to 25 September, 1995, on board the Norwegian RV 'Jan Mayen' Sedıments were sampled in several fjords near coastal Norway and the Svalbard archipelago, with emphasis on sites at Svalbard (Fig. 1, Table 1). Two stations, Sv 2 at Hornsund and Sv 3 at Van Mijen fjord, were visited on the western side of Svalbard, where the Western Spitsbergen current flows north along the coast keeping the fjords ice-free for most of the year (Andruleit et al. 1996). One site, Storfjorden (Sv 5), was sampled on the eastern side of Svalbard, which is influenced by colder polar currents originating from the Arctic Ocean (Andruleit et al. 1996). Overall, the Svalbard region, situated well above the Arctic Circle, is characterized 


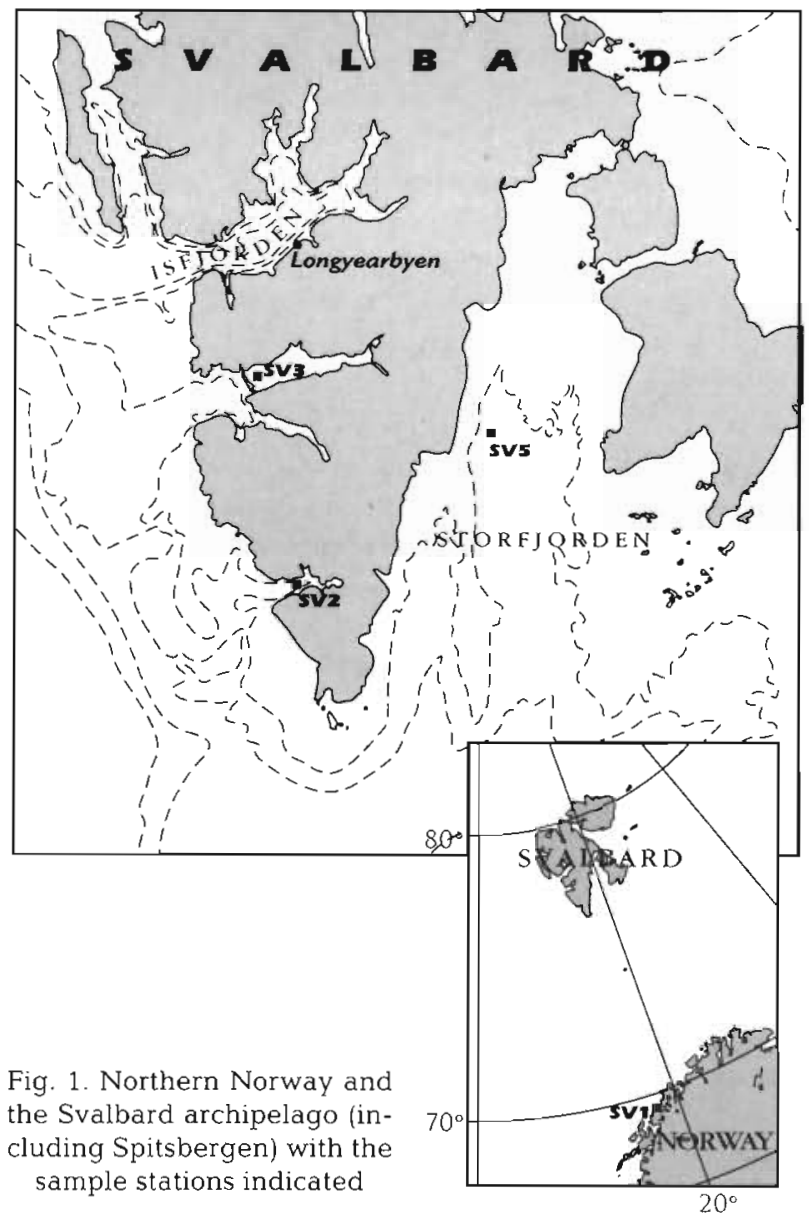

by consistently cold bottom water temperatures and an extended period of ice cover. Bottom water temperatures are provided in Table 1. All bottom waters contained $\mathrm{O}_{2}$ concentrations near saturation, and nitrate concentrations ranged from 9 to $12 \mu \mathrm{M}$ (Glud et al. 1998).

Table 1. Sample site information and sediment characteristics

\begin{tabular}{|c|c|c|c|c|}
\hline Stn: & Sv 1 & Sv 2 & Sv 3 & Sv 5 \\
\hline \multicolumn{5}{|l|}{ Position } \\
\hline Latitude & $69^{\circ} 29.4^{\prime} \mathrm{N}$ & $76^{\circ} 58.2^{\prime} \mathrm{N}$ & $77^{\circ} 45.8^{\prime} \mathrm{N}$ & $77^{\circ} 33.0^{\prime} \mathrm{N}$ \\
\hline Longitude & $18^{\circ} 07.5^{\prime} \mathrm{W}$ & $15^{\circ} 34.5^{\prime} \mathrm{W}$ & $15^{\circ} 03.9^{\prime} \mathrm{W}$ & $19^{\circ} 05.0^{\prime} \mathrm{W}$ \\
\hline Water depth (m) & 329 & 155 & 115 & 175 \\
\hline $\begin{array}{l}\text { Bottom water } \\
\text { temperature }\left({ }^{\circ} \mathrm{C}\right)\end{array}$ & 7.0 & 2.6 & 0.2 & -1.7 \\
\hline Wet density $\left(\mathrm{g} \mathrm{cm}^{-3}\right)^{a}$ & 1.30 & 1.29 & 1.32 & 1.25 \\
\hline Porosity ${ }^{a}$ & 0.79 & 0.83 & 0.77 & 0.83 \\
\hline Organic C $(\%)^{\mathrm{b}}$ & 0.6 & 1.5 & 1.8 & 2.4 \\
\hline $\begin{array}{l}\text { Sediment accumulation } \\
\qquad\left(\mathrm{g} \mathrm{m}^{-2} \mathrm{~d}^{-1}\right)^{\mathrm{b}}\end{array}$ & 2.8 & 12.9 & 5.3 & 3.8 \\
\hline $\mathrm{O}_{2}$ penetration depth $(\mathrm{cm})$ & a) $)^{\mathrm{b}} 1.0$ & 0.6 & 1.0 & 1.1 \\
\hline
\end{tabular}

Primary production in the Barents Sea near Svalbard is estimated at up to $150 \mathrm{~g} \mathrm{C} \mathrm{m}^{-2} \mathrm{yr}^{-1}$ and undergoes a large seasonal variation similar to other seasonally icecovered areas (Eilertsen et al. 1989). Relevant sediment characteristics are given in Table 1. In general, sediments sampled for the present study were a clayey silt with relatively few drop stones ( $<1 \%$ by volume) in the upper $25 \mathrm{~cm}$. Sediment accumulation rates were determined from the depth distribution of unsupported ${ }^{210} \mathrm{~Pb}$ and were relatively rapid (Table 1 ). Organic C concentrations varied between 0.6 and $2.4 \%$, gradually decreasing with depth; this range in organic $\mathrm{C}$ concentrations overlapped with those observed for areas of the Svalbard shelf visited by Hulth et al. (1996). Bioirrigating macrofauna were observed to be abundant and were estimated to enhance benthic exchange rates by up to a factor of 3 in the sediments sampled for this study. Sediment mixing, presumably due to bioturbating fauna, was inferred from the ${ }^{210} \mathrm{~Pb}$ profiles (Glud et al. 1998), and benthic fauna caused heterogenous $\mathrm{O}_{2}$ profiles as measured with microelectrodes.

Sediment sectioning and pore water extraction. Sediments were sampled by a multicoring device in polycarbonate liners $(9.6 \mathrm{~cm}$ id) at all stations (Barnett et al. 1984). Eight to 10 cores were used and only accepted when the surface appeared to be unaffected by resuspension or disruption during coring. Cores were immediately transferred to an incubator set to bottom water temperature while sectioning at each station. A large advantage of the Svalbard sites was that the air temperature was always close to $0^{\circ} \mathrm{C}$ at the time of sampling, minimizing the warming of sediment during sectioning and sampling, which was conducted on deck.

For geochemical analyses, an additional 1 to 2 cores were sectioned within $1 \mathrm{~h}$ of retrieval and the sediment was loaded into polypropylene centrifuge tubes in a $\mathrm{N}_{2}$-filled glove bag. The tubes were tightly capped and centrifuged for 10 to $20 \mathrm{~min}$ in a cold room at $0^{\circ} \mathrm{C}$. After reintroduction into the glove bag, pore waters were sampled and filtered through $0.2 \mu \mathrm{m}$ cellulose acetate syringe filters. Sediments for solid phase analysis were frozen under $\mathrm{N}_{2}$ for later use.

For determination of $\mathrm{C}$ mineralization rates and pathways, sediment from the upper $10 \mathrm{~cm}$ of 8 to 10 cores (723 $\mathrm{cm}^{2}$ total) was incubated as described by Canfield et al. (1993b) and Thamdrup \& Canfield (1996) in laminated ethylvinyl alcohol plastic bags with a very low gas permeability (Kruse 1993). Briefly, the cores were 
sectioned and parallel sections pooled under strict anoxia in a glove bag. After sectioning, sediment from each of 8 depth intervals was placed into the bags within a few hours of core retrieval. Incubation bags were sampled initially, sealed, and incubated dry at bottom water temperature (Table 1). Bags were placed within larger $\mathrm{N}_{2}$-filled bags during incubation to further maintain anoxic conditions as per Canfield et al. (1993b). The bags were then sampled at regular intervals, and the pore waters were extracted by centrifugation/filtration as described above.

Sulfate reduction rates were determined twice on 10 $\mathrm{ml}$ splits of sediment with ${ }^{35} \mathrm{SO}_{4}{ }^{2-}$ (Jørgensen 1978) in $2 \mathrm{~h}$ incubations at bottom water temperature. At termination, the sediment was fixed in $20 \% \mathrm{Zn}$ acetate and frozen. The reduced ${ }^{35} \mathrm{~S}$ was recovered by distillation with boiling acidic $\mathrm{Cr}^{2+}$ solution using the single-step method of Fossing \& Jørgensen (1989). Sulfate reduction measurements were carried out in short-term incubations ( $2 \mathrm{~h}$ ) where the effects of sulfide oxidation (Fossing 1995) and calcium carbonate precipitation/ dissolution should be minimal.

Pore water analyses. Pore water for the determination of $\mathrm{CO}_{2}$ and ammonium analyses was filtered into $1.8 \mathrm{ml}$ glass vials that were capped with Teflon-coated butyl rubber septa, leaving no gas phase and maintaining anoxia. The samples were stored at $0^{\circ} \mathrm{C}$ and analyzed within a few days of sampling by flow injection with conductivity detection (Hall \& Aller 1992; $\mathrm{SD} 2 \%$ for both $\mathrm{\Sigma CO}_{2}$ and $\mathrm{NH}_{4}{ }^{+}$) on board ship. Hydrogen sulfide can interfere with $\Sigma \mathrm{CO}_{2}$ measurements with this method (Hall \& Aller 1992, Lustwerk \& Burdige 1995). However, no dissolved sulfide was detected (methylene blue method, det. limit $1 \mu \mathrm{M}, \mathrm{SD} 5 \%$; Cline 1969) in the top $10 \mathrm{~cm}$ of any of the pore waters sampled.

Concentrations of $\mathrm{NO}_{3}^{-}+\mathrm{NO}_{2}^{-}$were determined on frozen pore water after reduction with V(III) to NO with subsequent detection by chemiluminescence (det. limit $0.1 \mu M_{i}$ SD 1\%; Braman \& Hendrix 1989). Dissolved $\mathrm{Fe}^{2+}$ was determined immediately after filtration by colorimetry with a ferrozine solution (det. limit 1. $\mu \mathrm{M}$; SD $2 \%$; Stookey 1970). Dissolved $\mathrm{Mn}^{2+}$ was anaiyzed in acidified pore water by flame atomic absorption spectroscopy (det. limit $0.5 \mu M_{\text {; SD }} 2 \%$ ). Sulfate concentrations were measured in acidified pore water using the turbidometric method of Tabatabi (1974). Sediment pH was determined at the end of the incubations with a glass electrode, calibrated with NBS standards, that was inserted into the bags. For all pore water chemistry, samples from duplicate cores generally varied by no greater than $10 \%$ and usually were within $5 \%$ of the concentration average between cores.

Solid phase analyses. Wet chemical extractions were used to determine the poorly crystalline $\mathrm{Fe}$ and $\mathrm{Mn}$ oxide pools (Canfield 1989, Kostka \& Luther 1994, Thamdrup et al. 1994). Iron was extracted in $0.5 \mathrm{M} \mathrm{HCl}$ for 1 h (Kostka \& Luther 1994). The oxidation state of $\mathrm{Fe}$ in the extract was further determined by analysis in (a) ferrozine buffer $(50 \mathrm{mM}$ HEPES, $0.1 \%$ ferrozine, $\mathrm{pH} 7$ ), and (b) ferrozine buffer $+1 \%(\mathrm{w} / \mathrm{v})$ hydroxylamine hydrochloride ( $\mathrm{pH}$ 7) (Kostka \& Luther 1994). Iron determined in the $\mathrm{HCl}$ extract with hydroxylamine addition is operationally defined as the total $\mathrm{HCl}$-extractable fraction $[(\mathrm{Fe}(\mathrm{II})+\mathrm{Fe}(\mathrm{III})]$ while $\mathrm{Fe}$ in the $\mathrm{HCl}$ extract without hydroxylamine addition is defined as the HCl-extractable Fe(II). Solid Fe(III) was determined by difference between these 2 fractions. Calibration experiments with pure $\mathrm{Fe}$ phases have confirmed the selectivity of this extraction towards poorly crystalline Fe phases (Canfield 1988, Kostka 1993). Manganese was extracted with dithionite-citrateacetic acid (DCA; pH 4.8; Lord 1980, Canfield 1989) and $\mathrm{Mn}$ concentration was measured in extracts using the same method described above for pore waters.

Acid-volatile sulfide (AVS $=\mathrm{FeS}+\mathrm{H}_{2} \mathrm{~S}$ ) and chromium-reducible sulfur ( $\mathrm{CRS}=\mathrm{S}^{0}+\mathrm{FeS}_{2}$ ) were determined after a 2-step distillation with cold $2 \mathrm{M} \mathrm{HCl}$ and boiling $0.5 \mathrm{M} \mathrm{Cr}^{2+}$ solution (Fossing \& Jørgensen 1989). Elemental sulfur was extracted by shaking the samples in $100 \%$ methanol for $24 \mathrm{~h}$ and then determined with HPLC as in Ferdelman et al. (1997). Sediment fixed with $\mathrm{Zn}$ acetate from the sulfate reduction measurements was used for sulfur determinations. Concentrations of $\mathrm{FeS}$ and $\mathrm{FeS}_{2}$ were determined by difference (AVS $-\mathrm{H}_{2} \mathrm{~S}$ and CRS $-\mathrm{S}^{0}$, respectively). For all solid phase measurements, samples from duplicate cores generally varied by no greater than $10 \%$ and usually were within $5 \%$ of the concentration average between cores.

\section{RESULTS}

\section{Pore water chemistry}

Profiles of pore water constituents are presented to between 20 and $30 \mathrm{~cm}$ depth in the sediment. Oxygen penetration depths, measured in situ using a benthic lander, were observed at $1.0,0.6,1.0$ and $1.1 \mathrm{~cm}$ at Sv 1, Sv 2, Sv 3, and Sv 5 (Table 1). Nitrate concentrations (Fig. 2a.) were depleted to a few micromolar in the top $1 \mathrm{~cm}$ at all stations. Sulfate concentrations remained relatively constant at all stations with little or no depletion observed to below $20 \mathrm{~cm}$ (Fig. 2b). As mentioned previously, no dissolved sulfide was detected (to $<1 \mu \mathrm{M})$ in any of the pore waters at all stations.

Just below the sediment depth where oxygen and nitrate were depleted, subsurface maxima were observed for pore water $\mathrm{Mn}$ at 1 to $2 \mathrm{~cm}$ (Fig 2c) and for 

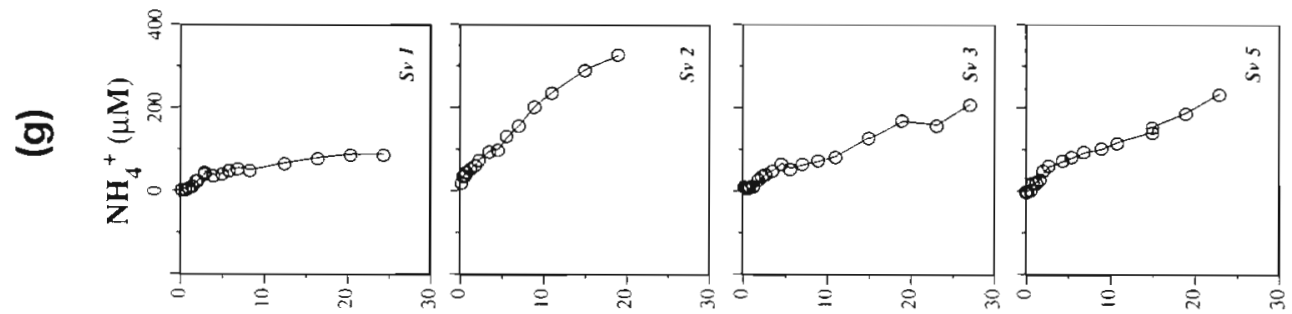

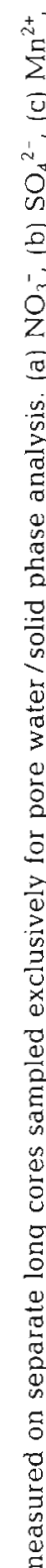
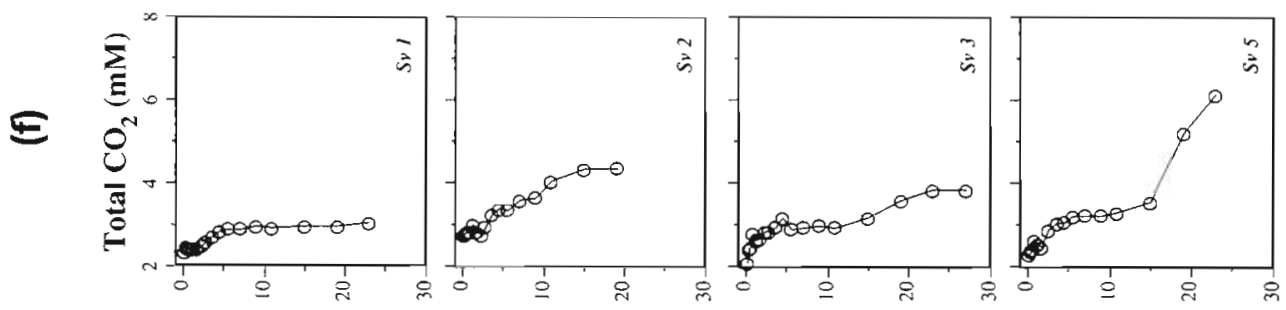

(I)

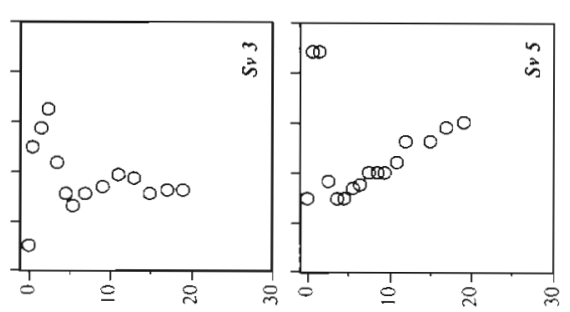

20
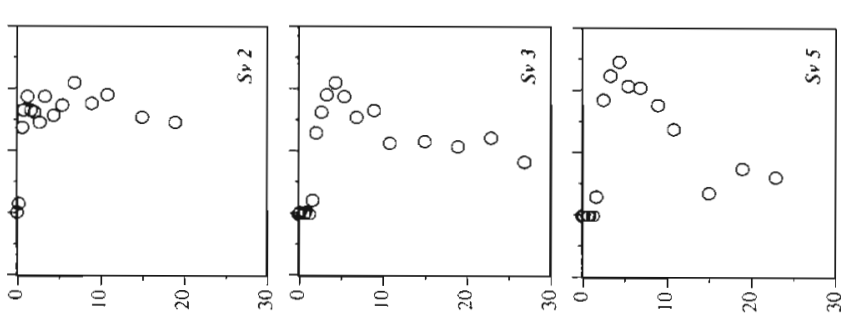

U1
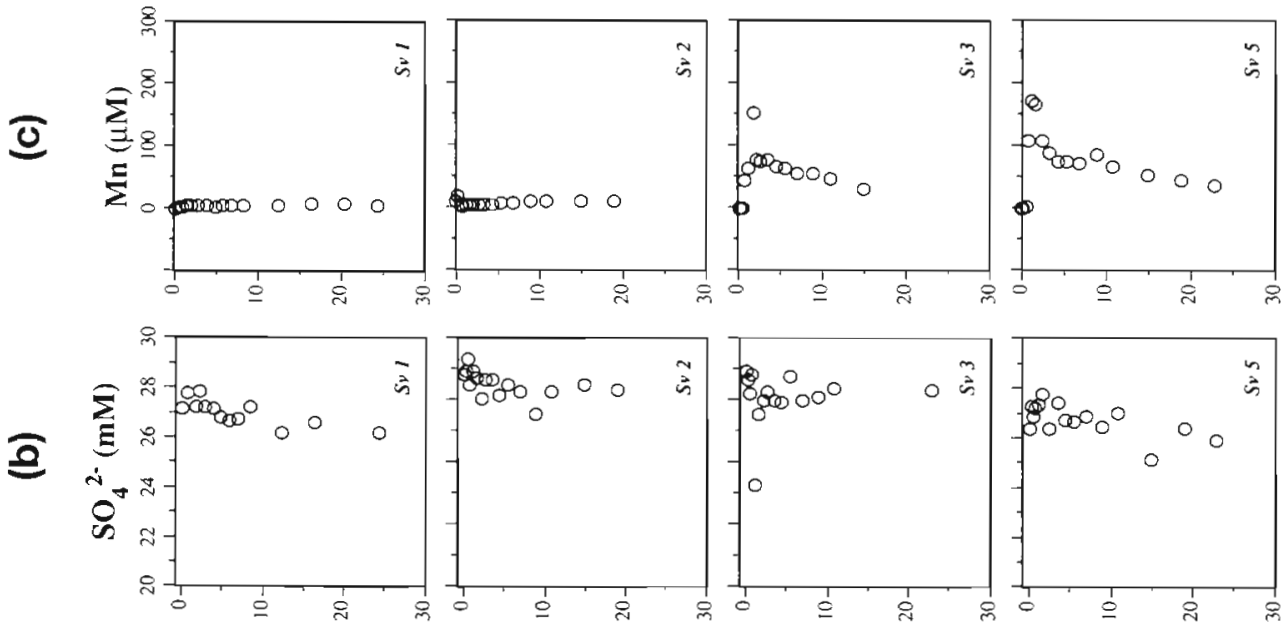

(I)

Depth (cm)

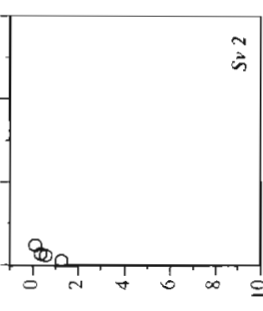

Depth (cm)

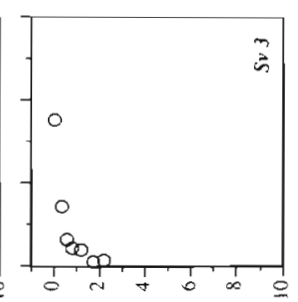

Depth (cm)

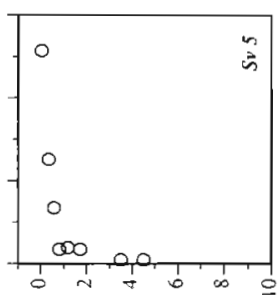

Depth (cm)

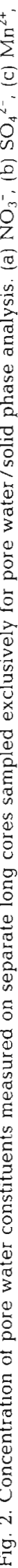


pore water $\mathrm{Fe}^{2+}$ at 2 to $6 \mathrm{~cm}$ (Fig. 2d), indicative of $\mathrm{Fe}$ and $\mathrm{Mn}$ reduction zones, respectively. Sediment $\mathrm{pH}$ distribution (Fig. 2e) followed closely with the redoxsensitive pore water constituents, showing larger vertical gradients at stations where larger gradients of solid phase $F e, M n$ were observed close to the sediment surface (Sv 3, Sv 5; Fig. 3).

Mineralization products, $\Sigma \mathrm{CO}_{2}$ and $\mathrm{NH}_{4}{ }^{+}$, exhibited parallel distributions and the curvature of the profiles (close to the sediment surface) was indicative of relatively rapid organic matter decomposition (Fig. 2f,g). Ammonium profiles were concave up, suggesting a significant effect of pore water irrigation to $\geq 10 \mathrm{~cm}$ depth, especially at Sv 3 and Sv 5.

\section{Solid phase distributions}

Solid phase concentrations are presented to $10 \mathrm{~cm}$ depth on a per volume basis in order that the distributions may be more easily compared to rate measure-
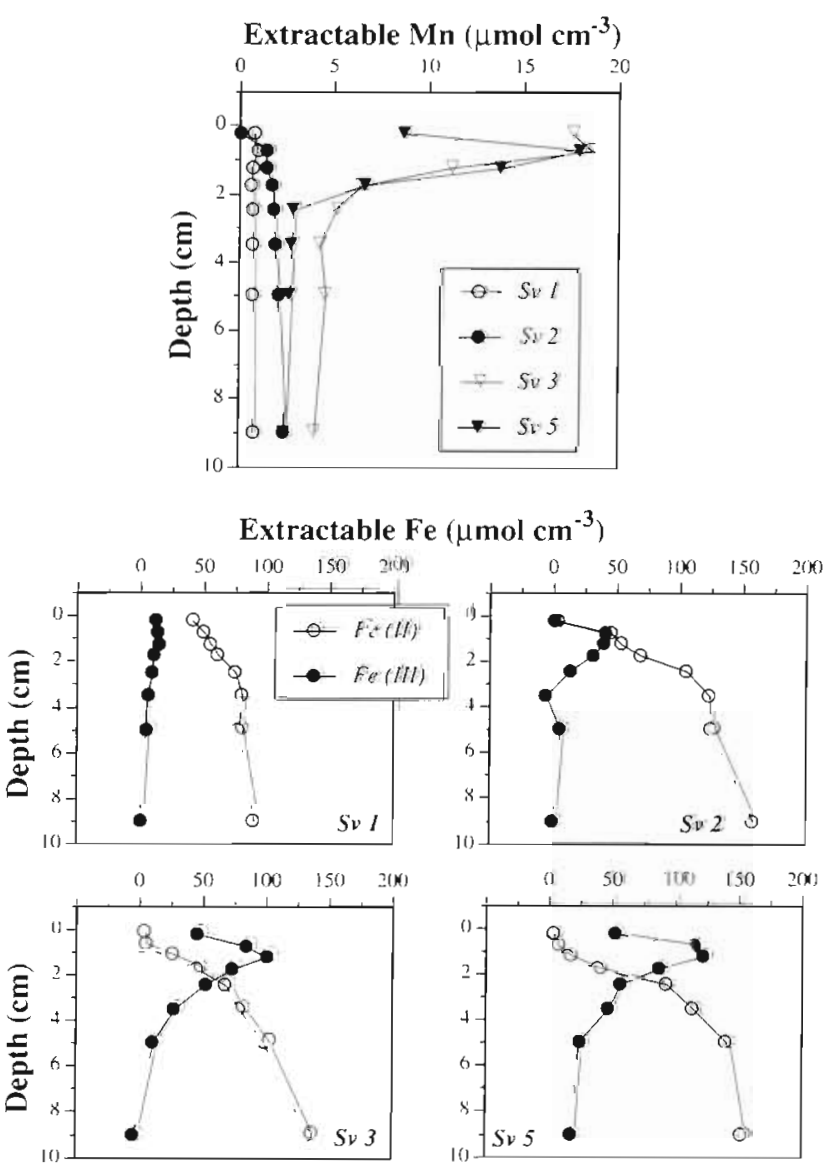

Fig. 3. Solid phase extractable Fe(III) and Mn(IV) indicative of the poorly crystalline metal oxides available for biological and chemical reduction. Solid $\mathrm{Fe}$ is further speciated into reduced and oxidized pools (see 'Methods') ments. Wet chemical extractions were used to determine the poorly crystalline Fe and Mn oxide pools, as these compounds are thought to be available for bacterial respiration (Lovley \& Phillips 1986, Lovley 1991). The total amount of poorly crystalline Fe oxide [hereafter referred to as solid Fe(III)] extracted was on the high end of the range observed in temperate marine sediments in the subtidal zone (Canfield 1989. Thamdrup et al. 1994, Thamdrup \& Canfield 1996) indicating a large amount of reactive Fe(III) was available for respiration. Similar solid Fe(III) concentrations were measured at all stations sampled on Svalbard (Sv 2 through Sv 5), and about half the amount of Fe(III) was extracted at Sv 1 (Fig, 3). A large gradient in solid Fe(III), consistent with the corresponding vertical pore water Fe gradient (Fig. 2d), was observed at Sv 3 and Sv 5 from 1 to $4 \mathrm{~cm}$ depth, while a smaller solid Fe(III) gradient was observed at Sv 2 and the whole profile was shifted closer to the sediment surface (Fig. 3). At Sv 1, the majority of extracted Fe was reduced at all sediment depths and Fe(III) concentrations were lower than at all other stations.

The range of poorly crystalline $\mathrm{Mn}$ oxide (hereafter referred to as solid $\mathrm{Mn}$ ) concentrations was approximately 10 times lower than solid Fe(III) (Fig. 3), while the vertical distributions of solid $\mathrm{Mn}$ and Fe were similar Substantial depth gradients of solid Mn were only observed at stations Sv 3 and Sv 5 close to the sediment surface with vertical distributions mirroring those of pore water Mn (Fig. 2c).

At all stations, solid $S$ fractions (pyrite, AVS, $\mathrm{S}^{0}$; see Fig. 4) increased with sediment depth. The highest solid S concentrations were observed at Sv 2 with much lower concentrations at the other 3 stations. Pyrite was the dominant solid $\mathrm{S}$ pool at all stations. Solid $S$ concentrations were an order of magnitude lower than solid Fe concentrations at all stations and were in the middle of the range observed in shallow, temperate continental margin sediments (Jørgensen 1977, Fossing \& Jørgensen 1989, Canfield et al. 1993b). The calculated burial of reduced $\mathrm{S}\left(=\mathrm{H}_{2} \mathrm{~S}+\mathrm{S}^{0}+\mathrm{FeS}+\right.$ $\mathrm{FeS}_{2}=\mathrm{AVS}+\mathrm{CRS}$ ) below $10 \mathrm{~cm}$ was 0.033 to $0.8201 \mathrm{mmol} \mathrm{m} \mathrm{m}^{-2} \mathrm{~d}^{-1}$, accounting for only $<1$ to $7 \%$ of the daily integrated sulfate reduction rate, consistent with the rapid recycling or reoxidation of sulfides at the top of the sulfate reduction zone. Burial was calculated using the total concentration of reduced $\mathrm{S}$ at the deepest depth sampled (Fig. 4) multiplied by the sediment accumulation rate

\section{Rate measurements in sediment incubations}

In order to constrain the amount of $\mathrm{C}$ oxidation coupled to various respiration pathways, we have mea- 


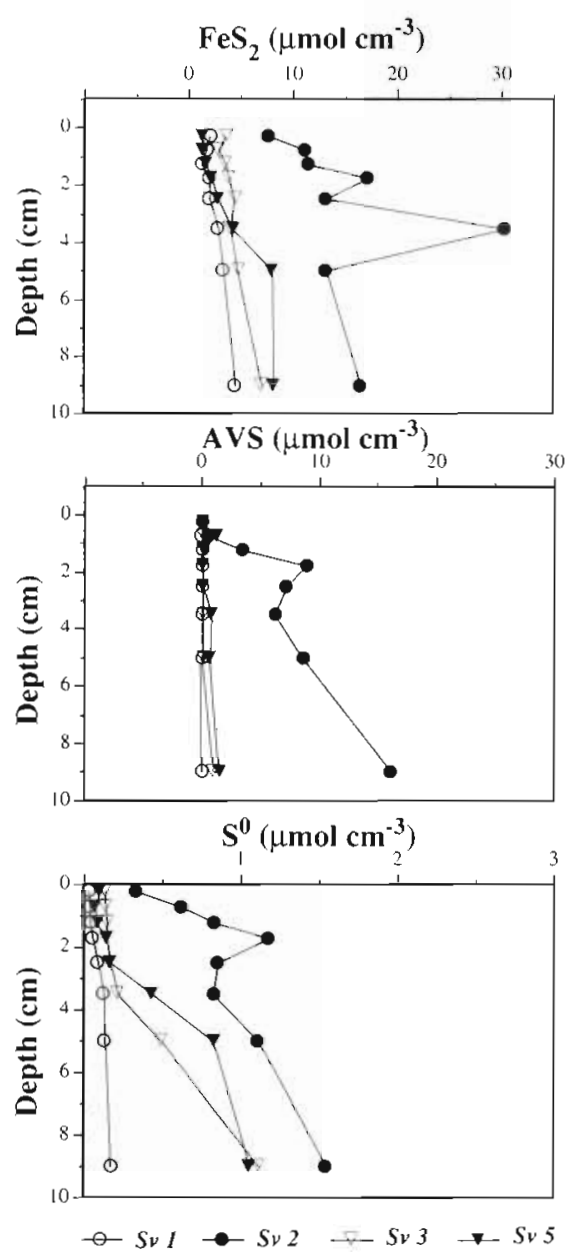

Fig. 4. Solid phase reduced S pools which are the products of bacterial sulfate reduction

sured the total accumulation of mineralization products $\left(\sum \mathrm{CO}_{2}\right.$ and $\left.\mathrm{NH}_{4}{ }^{+}\right)$, sulfate reduction rates, and denitrification rates in sediment samples at high resolution to $10 \mathrm{~cm}$ depth. The accumulation of mineralization products was measured in $60 \mathrm{~h}$ incubations and the rate of accumulation was calculated by regression of the increase in concentration vs time. In general, production rates were highly linear showing no systematic deviation with time as shown for Sv 2 in Fig. 5. In duplicate core incubations, mineralization rates agreed to within $10 \%$ of the average rate between incubations, and agreement was usually better than $7 \%$.

Rates of $\Sigma \mathrm{CO}_{2}$ and ammonium accumulation first decreased with depth and then showed a mid-depth maximum near that of surface rates centered around 2 to $3 \mathrm{~cm}$ depth at all stations (Figs. $6 \& 7$ ). The middepth maximum could be the result of sediment mixing or a focusing of organic material caused by the high macrofaunal activity in the area. The depth-integrated $\mathrm{C}$ oxidation rate at Hornsund ( $\mathrm{Sv} 2$ ) was nearly twice that measured at other stations, whereas the

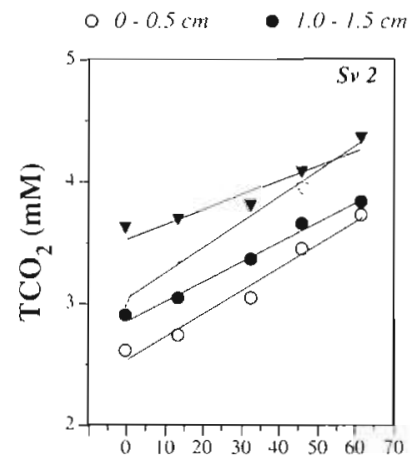

Time (hours)

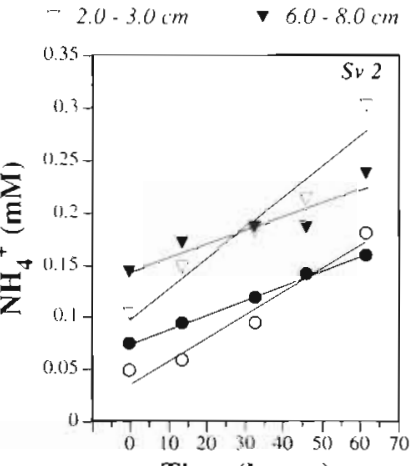

Time (hours)
Fig. 5. Examples of the accumulation of $\mathrm{SCO}_{2}$ and $\mathrm{NH}_{4}{ }^{+}$over time in pooled sediment incubations at Hornsund fjord (Sv 2)

ammonium accumulation rate was similar in magnitude at Sv1, Sv2, and Sv 3 (Table 2). The unusually high integrated ammonium accumulation rate observed at Sv 5 (Table 2) largely originates from the high rate measured in the 4 to $6 \mathrm{~cm}$ depth interval (Fig. 7), which also produced a very low $\mathrm{C} / \mathrm{N}$ ratio of mineralization products (Table 2).

In general, the $\mathrm{C} / \mathrm{N}$ ratio of mineralization products varied greatly and for some stations was low relative to Redfield stoichiometry (Redfield 1958) and to other studies (Thamdrup \& Canfield 1996). Low C/N ratios

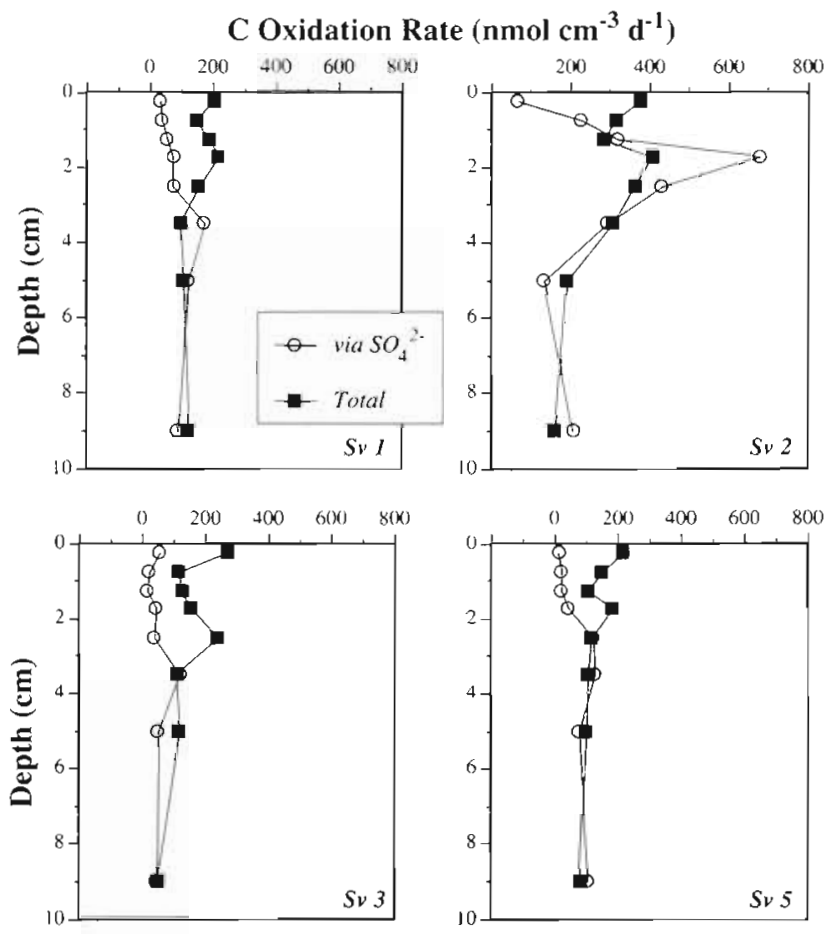

Fig. 6. Total carbon oxidation rates (from $\Sigma \mathrm{CO}_{2}$ accumulation) and the carbon oxidation equivalents derived from independently measured sulfate reduction rates from sediment. incubations 

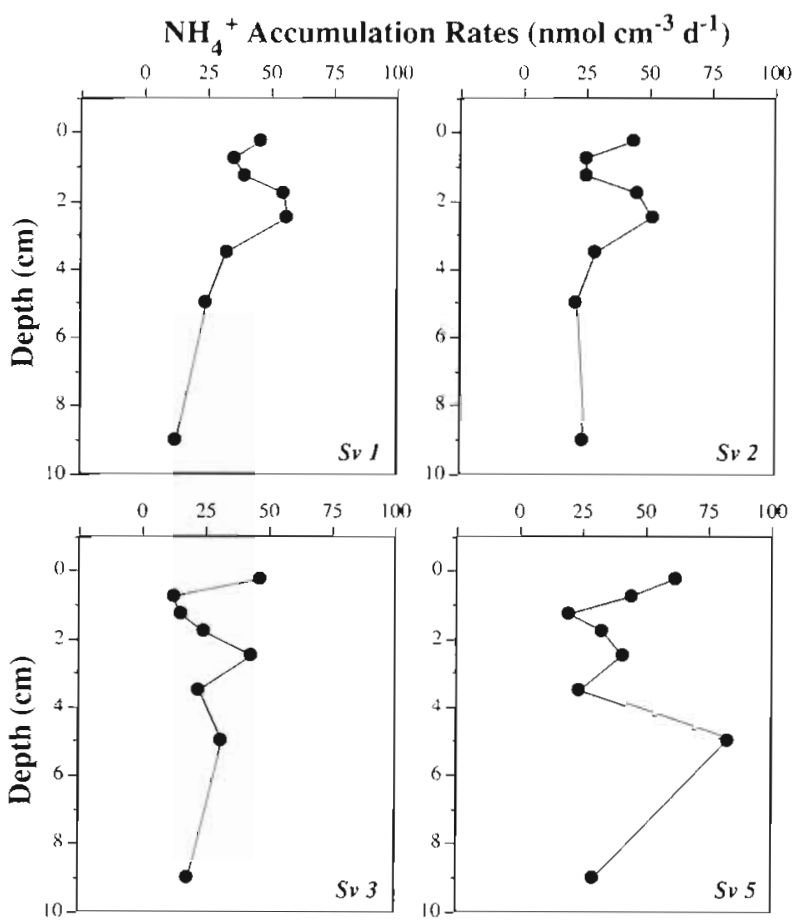

Fig. 7. Accumulation rates of $\mathrm{NH}_{4}{ }^{+}$in the pore waters of sediment incubations

$(<6)$ could result from the oxidation of short chain fatty acids which do not contain $\mathrm{N}$ or the assimilation of $\mathrm{N}$ from dissolved $\mathrm{NH}_{4}{ }^{+}$. The highest $\mathrm{C} / \mathrm{N}$ ratio of 10 was observed at the station with the highest mineralization rates, Sv 2 (Table 2 ).

Rates of sulfate reduction (Fig. 8) were depressed in all surface sediments sampled, generally in the 0 to $4 \mathrm{~cm}$ depth zone, indicating that other respiratory processes dominated $\mathrm{C}$ oxidation in this zone. At Sv2, average sulfate reduction rates were 3 to 5 times higher than at the other stations, and the rate maximum was observed closer to the sediment surface at 1.5 to $2.0 \mathrm{~cm}$ depth. Higher sulfate reduction activity at Sv 2 was also evidenced by high integrated rates

Table 2. Depth-integrated rates of respiration and the accumulation of mineralization products $\left(\mathrm{mmol} \mathrm{m} \mathrm{m}^{-2} \mathrm{~d}^{-1}\right)$ in the 0 to $10 \mathrm{~cm}$ depth range

\begin{tabular}{|c|c|c|c|c|c|}
\hline Stn & $\begin{array}{c}\mathrm{\Sigma CO}_{2} \\
\text { accumulation }\end{array}$ & $\begin{array}{c}\mathrm{NH}_{4}{ }^{+} \\
\text {n accumulation }\end{array}$ & $\begin{array}{l}\mathrm{SO}_{4}^{2-} \\
\text { reduction }\end{array}$ & $\begin{array}{l}\text { Denitri- } \\
\text { fication }\end{array}$ & $\begin{array}{l}\mathrm{C} / \mathrm{N} \\
\text { ratio }\end{array}$ \\
\hline Sv-1 & 13.3 & 2.9 & 5.0 & 0.2 & 4.7 \\
\hline Sv-2 & 24.2 & 2.8 & 12.0 & 0.6 & 9,4 \\
\hline Sv-3 & 11.9 & 2.6 & 2.6 & 0.3 & 5.9 \\
\hline Sv-5 & 11.0 & 4.8 & 4.4 & 0.2 & 3.7 \\
\hline
\end{tabular}

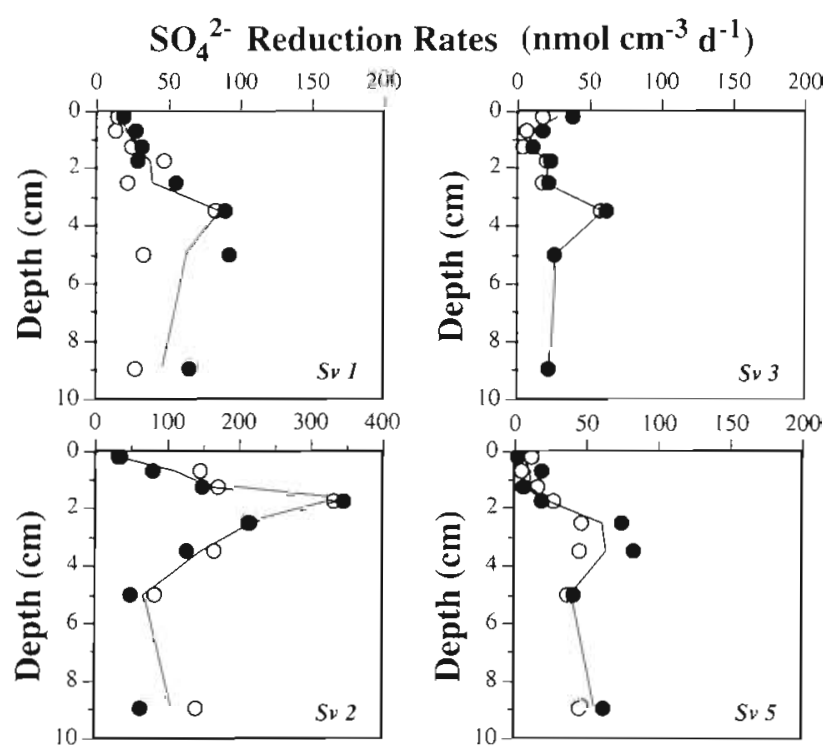

Fig. 8. Sulfate reduction rates measured in sediment incubations. Bold lines represent the averages of duplicate rate measurements

(Table 2). The remaining stations showed a maximum sulfate reduction rate of 60 to $100 \mathrm{nmol} \mathrm{cm} \mathrm{cd}^{-1}$ at 3.0 to $4.0 \mathrm{~cm}$ depth. Denitrification rates, measured using the isotope-pairing technique (Nielsen 1992), were were 2 to 3 times higher at Sv 2 compared to the other stations (Table 2).

Direct rate measurements together with the distribution of potential oxidants were used to completely partition microbial respiration pathways. A concise description of the deduction scheme used in this study can be found in Thamdrup \& Canfield (1996), and the stoichiometries of respiration reactions used during data interpretation can be found in Canfield et al. (1993a). In Fig. 6, sulfate reduction rates have been converted to the amount of $\mathrm{C}$ oxidized using a $2: 1$ stoichiometry of $\mathrm{C}$ oxidized to sulfate reduced (Thamdrup \& Canfield 1996). C oxidation via sulfate reduction is then compared with the total $\mathrm{C}$ oxidation rates derived from $\Sigma \mathrm{CO}_{2}$ accumulation in sediment incubations. The rates converge at depth at all stations, indicating that sulfate reduction is the dominant respiratory process, whereas the rates diverge in surface sediments, indicating that other respiration pathways are operative. Our incubations were not long enough to accurately measure the stoichiometry of $\mathrm{SO}_{4}{ }^{2-}$ depletion to $\Sigma \mathrm{CO}_{2}$ accumulation. However, the match of radiotracer-derived sulfate reduction rates to total $\mathrm{C}$ oxidation rates at depth is a good indication that the $\mathrm{SCO}_{2}: \mathrm{SO}_{4}^{2-}$ relationship holds for this study.

Manganese accumulation rates calculated by linear regression of sediment incubation results are provided in Fig. 9. These rates scaled with the solid phase Mn 

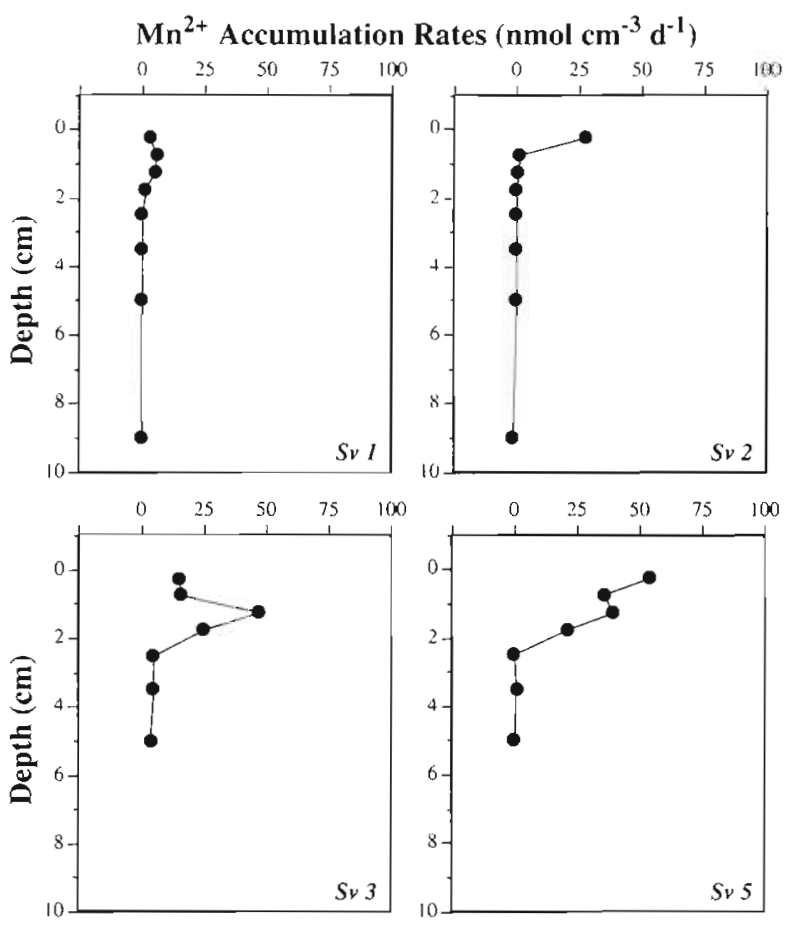

Fig. 9. Accumulation rates of $\mathrm{Mn}^{2+}$ in the pore waters of sediment incubations

concentrations (Fig. 3) with the highest rates observed at Sv 3 and Sv 5 , followed by Sv 2 and Sv 1, respectively. Iron accumulation rates measured in sediment incubations were not as easily evaluated as those for $\mathrm{Mn}$. Accumulation appeared to be largely affected by adsorption and precipitation reactions (data not shown). However, Fe(II) accumulation was generally observed only at sediment depths where the Fe(III) reduction zone was delineated by a gradient in solid phase Fe(III).

The lack of significant gradients of solid $\mathrm{Mn}$ in the 0 to $1 \mathrm{~cm}$ depth interval at Sv 1 and Sv 2 (avg solid $\mathrm{Mn}<1 \mu \mathrm{mol} \mathrm{cm}{ }^{-3}$; Fig. 3) suggest that insignificant $\mathrm{Mn}(\mathrm{IV})$ is available for reduction at these stations. In contrast, substantial gradients in solid $\mathrm{Mn}$ were observed at Sv 3 and Sv 5. Dissimilatory Mn(IV) reduction by metal-reducing bacteria has been shown to outcompete abiotic reduction reactions coupled to AVS, $S^{0}$ (Aller \& Rude 1988, Canfield et al. 1993b), and $\mathrm{Fe}^{2+}$ oxidation (Postma 1985, Burdige \& Nealson 1986). Assuming that sediment solids are mixed in a diffusional manner, we can compare gradients of solid $\mathrm{Mn}$ with those of potential reductants (AVS, $\mathrm{S}^{0}, \mathrm{Fe}^{2+}$ ) to evaluate abiotic and biotic reduction pathways (see also Canfield et al. 1993b).

Given that bioturbation mixes both oxidant and reductant at a rate proportional to their concentration gradients, chemical gradients of all reductant species
Table 3 . Solid phase and pore water gradients in the Mn(IV) reduction zone $(0.5$ to $2.0 \mathrm{~cm}$ depth). AVS $=$ acid-volatile sulfide

\begin{tabular}{|c|c|c|c|c|c|}
\hline \multirow[t]{2}{*}{ Stn } & \multicolumn{5}{|c|}{ Gradient $\left(\mu \mathrm{mol} \mathrm{cm}{ }^{-4}\right)$} \\
\hline & Mn oxide & AVS & $S^{0}$ & $\mathrm{Fe}^{2+}$ & $\mathrm{Fe}(\mathrm{II})^{\mathrm{a}}$ \\
\hline Sv 3 & 12.1 & 0.006 & 0.009 & 0.016 & 43.4 \\
\hline Sv 5 & 11.4 & $(-)$ & 0.080 & 0.016 & 38.7 \\
\hline \multicolumn{6}{|c|}{$\begin{array}{l}\text { 'Extractable Fe(II), presumed to be adsorbed and there- } \\
\text { fore reactive toward Mn(IV) }\end{array}$} \\
\hline \multicolumn{6}{|c|}{$2 \mathrm{Fe}^{2+}+\mathrm{MnO}_{2}+2 \mathrm{H}_{2} \mathrm{O} \longrightarrow 2 \mathrm{FeOOH}+\mathrm{Mn}^{2+}+2 \mathrm{H}^{+}$} \\
\hline
\end{tabular}

except solid phase, extractable Fe(II) are at least 3 orders of magnitude too low to support reduction of the solid Mn present (Table 3). However, adsorbed Fe(II), which would only be observed in the solid phase extractions, is available to react with poorly crystalline Mn oxides (see balanced reaction in Table 3). The demand of solid Mn for reduction is more than balanced by the solid Fe(II) available for oxidation (Table 3). We conclude the consumption of solid $\mathrm{Mn}$ is due to the abiotic reduction by adsorbed Fe(II) or soluble $\mathrm{Fe}(\mathrm{II})$ desorbed from the solid phase, and not due to dissimilatory reduction by bacteria (at Sv 3 and Sv 5). Therefore, after subtracting out $\mathrm{C}$ mineralized via $\mathrm{SO}_{4}{ }^{2-}$ reduction, all of the remaining $\mathrm{C}$ oxidation in the suboxic zone is coupled to dissimilatory Fe(III) reduction. This interpretation also follows for the profiles of solid $\mathrm{Mn}$ and $\mathrm{Fe}$ observed at $\mathrm{Sv} 1$. Extractable $\mathrm{Fe}$ (II) is high to the sediment surface while little or no maximum in solid Mn was observed (Fig. 3).

\section{DISCUSSION}

\section{Pore water and solid phase geochemistry}

Geochemical gradients resulting from the consumption of oxidant and the accumulation of reduction products in shallow polar sediments are consistent with a diagenetically active system containing the same vertical sequence of microbial respiration reactions found in temperate marine sediments exposed to relatively high sedimentation rates. There was substantial overlap between redox zones, especially in suboxic areas of the sediments. As observed for temperate shelf sediments exposed to relatively high C deposition (Canfield et al. 1993b), oxygen and nitrate were depleted in the top $1 \mathrm{~cm}$ depth of the sediment at all stations, indicative of active aerobic respiration and denitrification in this zone. Immediately below, at 1 to $2 \mathrm{~cm}$ depth, chemical gradients of Mn revealed a distinct $\mathrm{Mn}$ (IV) reduction zone which was interpreted to 
be supported by abiotic reduction reactions. Overlapping by $1 \mathrm{~cm}$ below the Mn(IV) reduction zone, a broader Fe(III) reduction zone $(1.5$ to $5 \mathrm{~cm})$ was observed from gradients in solid phase Fe. Products of sulfate reduction (solid phase reduced $\mathrm{S}$ compounds) showed that this zone overlapped extensively with that of metal reduction.

\section{Mineralization rates under permanently cold conditions}

Few studies have directly measured rates of organic mineralization in permanently cold sediments with most researchers having used oxygen fluxes to infer rates of C oxidation (Pfannkuche \& Thiel 1987, Grebmeier \& McRoy 1989, Henriksen et al. 1993, Nedwell et al. 1993, Rysgaard et al. 1996). O $\mathrm{O}_{2}$ uptake rates of up to $25 \mathrm{mmol} \mathrm{m}^{-2} \mathrm{~d}^{-1}$ were observed in shelf sediment of the Bering/Chukchi Seas (Henriksen et al. 1993), and a range of 11 to $17.8 \mathrm{mmol} \mathrm{m} \mathrm{m}^{-2} \mathrm{~d}^{-1}$ was found in the eastern Arctic, (Hulth et al. 1994, Rysgaard et al. 1996),

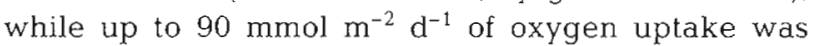
measured in the South Orkney Islands, Antarctica (Nedwell et al. 1993). As long as denitrification rates are low, the amount of $\mathrm{O}_{2}$ uptake should be roughly equal to the total $\mathrm{C}$ oxidation rate in marine sediment (Canfield et al. 1993a), and the range of our directly measured integrated $C$ oxidation rates $(10$ to $25 \mathrm{mmol}$ $\mathrm{m}^{-2} \mathrm{~d}^{-1}$; Table 2, Fig. 6) is nearly identical to that of previously measured $\mathrm{O}_{2}$ uptake rates in Arctic sedi-

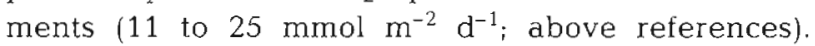
Furthermore, $\mathrm{C}$ mineralization rates from this study largely overlap with the range of rates reported for temperate shelf sediments $\left(2\right.$ to $28 \mathrm{mmol} \mathrm{m} \mathrm{m}^{-2} \mathrm{~d}^{-1}$; Archer \& Devol 1992, Canfield et al. 1993b, Devol \& Christiansen 1993), strongly suggesting that microbial communities in polar sediments are capable of processing organic matter at rates no different from rates measured in temperate shelf environments.

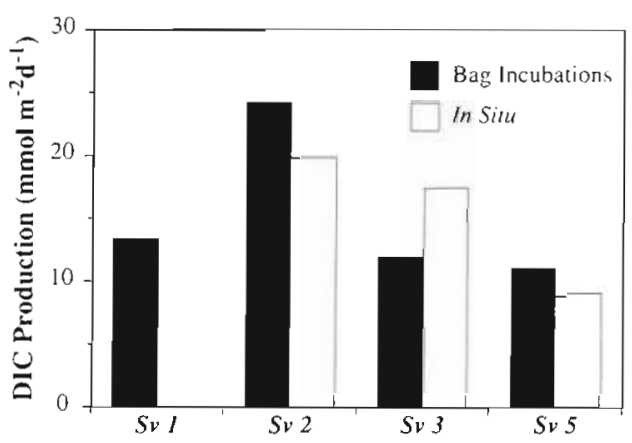

Fig. 10. Comparison of the depth-integrated (to $10 \mathrm{~cm}$ depth) $C$ oxidation rates measured in sediment incubations to those measured in situ using a free-vehicle benthic lander
To check for possible stimulation of microbial carbon mineralized in our bag incubation procedure, we have compared the depth-integrated $\mathrm{C}$ oxidation rates (measured by DIC accumulation) from incubations to DIC fluxes measured in situ using a free-vehicle benthic lander (Fig. 10). It was impossible to compare these approaches at Malangen Fjord (Sv1) because the benthic lander did not function properly. However, at the remaining stations, integrated rates of $\mathrm{C}$ oxidation measured using our bag incubation technique covaried and approached closely to the fluxes measured in situ to within a factor of 1.5 (Fig, 10).

Though pore water profiles indicate a significant portion of organic matter remineralization could occur below $10 \mathrm{~cm}$ depth, the bag incubations were only carried out to $10 \mathrm{~cm}$. Previous bag incubation studies compared $\mathrm{C}$ mineralization rates extending farther down in the sediment column to rates measured in intact cores as well as to in situ benthic fluxes (Thamdrup \& Glud unpubl.). The conclusion from these methodological studies was that the bag incubation technnique was consistent with other rate measurements, but in some cases, remineralization rates were enhanced in the bags by up to a factor of 2 . If we estimate approximately $50 \%$ of $\mathrm{C}$ mineralization is occurring below $10 \mathrm{~cm}$ depth in the sediments of this study (B. B. Jørgensen unpubl. results), it would follow that the $C$ oxidation rates from bags (Fig. 10) could be stimulated by a factor of 2 , making thern equal to DIC fluxes measured in situ.

The bag incubation technique also may cause the artificial elimination of a certain amount of $\mathrm{O}_{2}$ from the sediment. We assume aerobic respiration and denitrification are not significantly coupled to $\mathrm{C}$ oxidation below the depths to which $\mathrm{O}_{2}$ and nitrate penetrate. However, because abundant macrofauna (which potentially bioirrigate) were observed at all sites sampled, $\mathrm{O}_{2}$ removal could affect most of the depths sampled. As discussed above, $\mathrm{C}$ mineralization rates from bag incubations were similar to those measured by an in situ benthic lander. Because in situ $\mathrm{O}_{2}$ fluxes and sulfate reduction rates from bag incubations also scaled closely with measured $\mathrm{C}$ oxidation rates, the $\mathrm{O}_{2}$ flux roughly balances the demand for the reoxidation of reduction products (Canfield et al. 1993a), and we maintain that any $\mathrm{O}_{2}$ artifacts caused by the bag incubations should be minimal. Despite the additive variability inherent to all of the measurements that bag incubations incorporate, we contend rate measurements using this technique are internally consistent, and the partitioning of microbial respiration pathways is not signficantly altered. Our interpretation is supported by the match of measured sulfate reduction and $\sum \mathrm{CO}_{2}$ production rates at sediment depths where $\mathrm{SO}_{4}{ }^{2-}$ is the only oxidant available for respiration. The 
match of sulfate reduction and $\Sigma \mathrm{CO}_{2}$ production rates also indicated that little or no precipitaton/dissolution of $\mathrm{CaCO}_{3}$ was occurring which might influence our measurement of total $\mathrm{C}$ oxidation.

\section{Partitioning of microbial respiration pathways}

Mineralization pathways, especially under suboxic/ anoxic conditions in polar enviromments, have been studied to a smaller extent (Nedwell 1989, Nedwell et al. 1993, Rysgaard et al. 1996). Previous studies used $\mathrm{O}_{2}$ fluxes and sulfate reduction rates to partition oxic/anoxic mineralization processes, finding that 12 to $32 \%$ of organic matter mineralization was anoxic. Using this simple comparison, our study found that a much higher percentage (60 to $90 \%$; Table 4) of $\mathrm{C}$ oxidation was mediated by anoxic processes. Previous estimates of anoxic mineralization in Arctic sediments may be lower than those described here due to longer incubation times used in previous sulfate reduction rate measurements ( 20 to $24 \mathrm{~h}$ ). Longer incubation times can be affected by sulfide oxidation to cause spuriously low rates of sulfate respiration (Fossing 1995). Another explanation could be that previous investigators did not include Fe(III) and Mn(IV) as potential oxidants for organic matter mineralization.

As has been found in previous studies of temperate continental margin sediments (Jørgensen 1977, 1982, Canfield et al. 1993b, Thamdrup \& Canfield 1996), sulfate reduction was the dominant microbial respiration pathway in permanently cold, Arctic sediments (Table 4 ), comprising 58 to $92 \%$ of the $\mathrm{C}$ oxidized. On the average, Fe(III) reduction was the second most important pathway, responsible for up to $26 \%$ of the $\mathrm{C}$ oxidized in Arctic sediments. In agreement with previous studies (Canfield et al. 1993b, Thamdrup \& Canfield 1996), the importance of aerobic respiration overlapped with Fe(III) reduction at 5 to $14 \%$ of the C oxidized (Table 4). Denitrification made up only 2 to $3 \%$ of the $\mathrm{C}$ oxidized, in agreement with previous studies of marine sediment overlain by an oxic water column.

For the first time, we show that Fe(III) reduction is a significant contributor to the terminal decomposition of organic matter in permanently cold marine sediments. These data support the small, but growing database which indicates that Fe(III) and $\mathrm{Mn}(\mathrm{IV})$ respiration support a substantial amount of $\mathrm{C}$ oxidation in a wide range of marine sediments, from the Amazon delta (Aller et al. 1986, 1996) to the Danish shelf (Canfield et al. 1993a,b), the Chilean margin (Thamdrup \& Canfield 1996), and shallow coastal embayments such as Long Island Sound (Aller 1994).

The importance of sulfate reduction to $\mathrm{C}$ oxidation (and rapid sulfate reduction rates) at all sites would
Table 4. Summary of the partitioning of $\mathrm{C}$ mineralization pathways at each station. Presented as the amount of $\mathrm{C}$ oxidation integrated to $10 \mathrm{~cm}$ depth from sediment incubations at each site in mmol m $\mathrm{m}^{-2} \mathrm{~d}^{-1}$ with the percentage of the total integrated $\mathrm{C}$ oxidation rate in parentheses

\begin{tabular}{|lccccr|}
\hline Stn & \multicolumn{1}{c}{$\mathrm{O}_{2}$} & $\mathrm{NO}_{3}{ }^{-}$ & \multicolumn{1}{c|}{$\mathrm{Fe}(\mathrm{III})$} & $\mathrm{Mn}(\mathrm{IV})$ & \multicolumn{1}{c|}{$\mathrm{SO}_{4}{ }^{2-}$} \\
\hline $\mathrm{Sv} 1$ & $1.51(11.3)$ & $0.25(1.9)$ & $2.15(16.2)$ & 0 & $9.41(70.6)$ \\
$\mathrm{Sv} 2$ & $1.13(4.7)$ & $0.75(3.1)$ & 0 & 0 & $22.34(92.2)$ \\
$\mathrm{Sv} 3$ & $1.58(13.3)$ & $0.37(3.2)$ & $3.05(25.7)$ & 0 & $6.89(57.8)$ \\
Sv 5 & $1.58(14.4)$ & $0.25(2.3)$ & $1.09(9.9)$ & 0 & $8.08(73.4)$ \\
\hline
\end{tabular}

appear to be at odds with the lack of sulfate depletion measured with depth in the pore waters. We suggest that pore water irrigation is occurring at rates similar to temperate marine sediments and is vital to the recycling of oxidant in these Arctic sediments.

We can further support our interpretation of Fe reduction processes by calculating the biodiffusion coefficients necessary to support the solid Fe(III) demand of dissimilatory and abiotic reduction combined. At Sv 2, no contribution of dissimilatory Fe(III) reduction was observed from rate measurements; therefore Table 5 provides biodiffusion coefficients for only Sv 1, Sv 3 , and Sv 5. The demand of Fe(III) necessary to support C oxidation was first calculated from the inferred $C$ oxidation rate (see above discussion) using a 4:1 stoichiometry of Fe reduced to $\mathrm{C}$ oxidized (Canfield et al. 1993a). The abiotic portion of Fe(III) reduction was obtained using the measured sulfate reduction rates adjusted for the stoichiometry of sulfide oxidation (Thamdrup et al. 1994; Table 5). The total demand for Fe(III) (dissimilatory + abiotic; $J_{\text {b1o }}$ ) together with the measured solid Fe(III) gradient $\left(\mathrm{d}_{\mathrm{vol}} / \mathrm{d} x\right)$ at each station was then utilized to derive a biodiffusion coefficient $\left(D_{\mathrm{b}}\right)$ (Table 5$)$. The resulting biodiffusion coefficients $\left(D_{\mathrm{b}}=0.010\right.$ to 0.15$)$, are well within the range of $D_{b}$ 's reported previously $\left(D_{\mathrm{b}} \approx 0.014\right.$ to $0.30_{i}$ Van Cappellen et al. 1993, Boudreau 1994) for shallow, temperate marine sediments with relatively rapid sediment accumulation rates $\left(0.1\right.$ to $\left.1.0 \mathrm{~cm} \mathrm{yr}^{-1}\right)$.

To further check the reliability of our interpretation, we used Eq. (3) from Boudreau (1994) to calculate biodiffusion coefficients based on measured sediment accumulation rates (Table 1). The $D_{b}$ s obtained from this alternative method were almost identical to those obtained from the Fe mass balance for the Svalbard stations Sv 3 and Sv 5 (Table 5). We contend that these coefficients of sediment mixing intensity, obtained from the balance of inferred rate measurements and measured Fe(III) gradients, support our interpretation of the importance of dissimilatory Fe(III) reduction to organic matter oxidation at the Svalbard sites.

In contrast, at $\mathrm{Sv} 1$, the $D_{\mathrm{b}}$ from the Fe mass balance was 10 times higher than that obtained from the sedi- 
Table 5. Comparison of biodiffusion coefficients required to produce the observed Fe demand at stations where dissimilatory Fe(III) reduction is significant using rate measurements/solid Fe(III) gradients and biodiffusion coefficients calculated from the measured sediment accumulation rates

\begin{tabular}{|c|c|c|c|c|c|}
\hline & $\begin{array}{l}\text { Inferred } \\
\text { rate } \\
\left(\mathrm{mmol} \mathrm{m}^{-2} \mathrm{~d}^{-1}\right)\end{array}$ & $\begin{array}{l}\text { Dissimilatory } \\
\text { demand } \\
\left(m \text { mol m-2 } \mathrm{d}^{-1}\right)\end{array}$ & $\begin{array}{c}\text { Abiotic } \\
\text { demand } \\
\left(\mathrm{mmol} \mathrm{m} \mathrm{m}^{-2} \mathrm{~d}^{-\mathrm{t}}\right)\end{array}$ & $\begin{array}{l}\text { Solid Fe(III) } \\
\text { gradient } \\
\left(\mu \mathrm{mol} \mathrm{cm}^{-4}\right)\end{array}$ & $\begin{array}{l}\text { Required } \\
D_{b} \\
\left(\mathrm{~cm}^{2} \mathrm{~d}^{-1}\right)\end{array}$ \\
\hline Sv 1 & 2.17 & 8.68 & 3.33 & -7.99 & $\begin{array}{l}0.15^{\mathrm{e}} \\
0.011^{\mathrm{f}}\end{array}$ \\
\hline Sv 3 & 3.05 & 12.2 & 1.73 & -53.8 & $\begin{array}{l}0.026^{\mathrm{e}} \\
0.022^{\mathrm{l}}\end{array}$ \\
\hline Sv 5 & 1.09 & 4.36 & 2.93 & -69.9 & $\begin{array}{l}0.010^{\mathrm{e}} \\
0.015^{t}\end{array}$ \\
\hline \multicolumn{6}{|c|}{$\begin{array}{l}3 \mathrm{H}_{2} \mathrm{~S}+2 \mathrm{FeOOH} \longrightarrow \mathrm{S}^{\circ}+2 \mathrm{FeS}+4 \mathrm{H}_{2} \mathrm{O} \\
\mathrm{S}^{\circ}+\mathrm{FeS} \longrightarrow \mathrm{FeS}_{2}\end{array}$} \\
\hline \multicolumn{6}{|c|}{$\begin{array}{l}\text { anferred rate of } C \text { oxidation attributed to dissimilatory Fe(III) reduction } \\
\text { (inferred from rate measurements in bag incubations and distribution of } \\
\text { potential oxidants; see 'Results' and 'Discussion') }\end{array}$} \\
\hline \multicolumn{6}{|c|}{$\begin{array}{l}\text { 'Demand of solid Fe(III) necessary to support dissimilatory reduction calcu- } \\
\text { lated as } 4 \times \text { the inferred C oxidation rate [stoichiometry of dissimilatory } \\
\text { Fe(III) reduction taken from Canfield et al. 1993] }\end{array}$} \\
\hline \multicolumn{6}{|c|}{$\begin{array}{l}{ }^{c} \text { Demand of solid Fe(III) necessary to reoxidize sulfide produced from sulfate } \\
\text { reduction calculated as } 2 / 3 \times \text { the integrated sulfate reduction rate from } \\
\text { stoichiometry of reactions shown above (as in Thamdrup et al. 1994) }\end{array}$} \\
\hline \multirow{2}{*}{\multicolumn{6}{|c|}{$\begin{array}{l}{ }^{\mathrm{d}} \text { Calculated from the interfacial gradient of solid Fe(III) according to Van } \\
\text { Cappellen (pers. comm.) (data shown in Fig. } 3 \text { ) } \\
\text { e Biodiffusion coefficient calculated from the total Fe demand }\left({ }^{b}+{ }^{c} \text { above) }\right. \\
\text { and the solid Fe(III) gradient with the following equation as described by } \\
\text { Goldberg \& Koide (1962) and Guinasso \& Schink (1975): }\end{array}$}} \\
\hline & & & & & \\
\hline \multicolumn{6}{|c|}{$J_{\mathrm{bio}}=-\mathrm{D}_{\mathrm{b}} \times \mathrm{d} C_{\mathrm{vol}} / \mathrm{d}_{x}$} \\
\hline \multicolumn{6}{|c|}{$\begin{array}{l}\text { 'Biodiffusion coefficient calculated from the sediment accumulation rate as } \\
\text { in Boudreau (1994) according to the following equation: }\end{array}$} \\
\hline \multicolumn{6}{|c|}{$D_{b}=15.7 w^{0.69}$} \\
\hline
\end{tabular}

tions. Amongst potential variables controlling $C$ oxidation pathways, organic matter input and macrofaunal activity are prominent. At higher $\mathrm{C}$ deposition rates, $\mathrm{O}_{2}$ is rapidly consumed in surface sediments and anoxic $\mathrm{C}$ oxidation pathways become important. Also the importance of suboxic electron acceptors $\left[\mathrm{NO}_{3}{ }^{-}, \mathrm{Fe}(\mathrm{III})\right.$, $\mathrm{Mn}(\mathrm{IV})]$ depends upon recycling/ rejuvenation via reoxidation reactions. It is thought that Fe(III) and Mn(IV), as solid electron acceptors, depend upon physical (Aller et al. 1986, 1996) or biological mixing (Aller 1994) to be significant contributors to $\mathrm{C}$ oxidation. Oxidant and reactive $C$ are mixed down into the sediment while soluble products of respiration diffuse out to be reoxidized in the oxic zone.

Hornsund Fjord (Sv 2), which displayed the highest $\mathrm{C}$ mineralization rates and sulfate reduction activity, also showed the highest sedimentation rate and a relatively shallow mixing zone (Table 1). Here it is suggested that a combination of high organic $\mathrm{C}$ deposition and lower rates of macrofaunal mixing contributed to the predominance of sulfate respiration. At Van Mijen (Sv 3) and Storfjorden (Sv 5), intermediate sediment accumulation rates were observed while a deeper mixing zone was detected. The

ment accumulation rate (Table 5). In addition, lower sediment mixing intensities and a shallower mixed zone were observed using radionuclide profiles at Sv 1 as compared to the Svalbard stations Sv2, Sv 3, and Sv 5 (Table 1). This would appear to be at odds with our interpretation that substantial dissimilatory Fe(III) reduction is occurring at Sv 1 . We suggest that the Fe cycle in sediments at Sv 1 is being supported by irrigation from a different benthic fauna relative to the Svalbard stations, resulting in a higher apparent biodiffusion coefficient from the Fe mass balance. That would explain how rapid metal reduction is supported at a lower mixing intensity relative to the Svalbard stations. It follows that a substantially different benthic fauna exists at Malangen Fjord which is much farther south and exhibits higher bottom water temperatures compared to the other stations. An alternative explanation would be that the kinetics of Fe sorption/reoxidation differ between Svalbard and the Norwegian coast.

We observed substantial variability in the partitioning of microbial respiration pathways between sta- importance of $\mathrm{Fe}(\mathrm{III})$ reduction at these sites, quantified from rate measurements and solid Fe gradients, is suggested to be stimulated by higher macrofaunal mixing rates together with slightly lower rates of organic matter accumulation.

An alternative explanation would be that the differences in partitioning of respiratory pathways are not site-specific but due to sample variability. Another confounding factor in these studies is the lateral advection of organic matter. Especially in the fjords surrounding Svalbard, most of the organic matter oxidized in the sediment is likely to originate from primary production occurring kilometers away as bottom currents mix allochthonous POC into the fjord over the sill (Reigstad \& Wassman 1996). This makes it difficult to construct a $\mathrm{C}$ budget for these sediments without more extensive, site-specific data. Future studies of Arctic sediments should focus on an interdisciplinary approach emphasizing direct rate measurements over seasonal cycles to answer the questions posed above. 


\section{Temperature limitation of organic mineralization}

The standing stock of microbial biomass (bacteria, protozoa, ciliates) in these cold Svalbard sediments was found to be similar to that of temperate marine sediments (Sahm \& Berninger 1998), Based on our observations of the rates/pathways of $C$ oxidation in Svalbard sediments, we conclude, that in polar sediments exposed to relatively high rates of organic matter deposition, microbial metabolism is able to rapidly mineralize a majority of the labile $\mathrm{C}$ deposited. Therefore, in polar shelf environments, microbial metabolism does not appear to be inherently limited by temperature. Bacterial metabolism may still be limited by an interaction of temperature and $C$ substrate in permanently cold environments as described by Pomeroy et al. (1991). However, high $C$ deposition appears to offset any low substrate affinity of cold-adapted microbial populations. Therefore, microbial communities in cold polar sediments exposed to relatively high $\mathrm{C}$ deposition appear to respond to the input/availability of organic matter over temperature.

\section{SUMMARY}

This study comprehensively characterizes the biogeochemistry and directly measures the rates/pathways of $\mathrm{C}$ oxidation in permanently cold Arctic sediments. For the first time, microbial respiration pathways coupled to organic matter mineralization are completely partitioned for polar sediments. Conclusions are as follows:

(1) Sediment biogeochemistry revealed reactants and products of microbial respiration indicating that the same hierarchy of oxidants is utilized by microbes in polar sediments as in temperate environments.

(2) Depth-integrated rates of total $C$ oxidation and sulfate reduction observed in cold sediments were no different from rates measured in temperate shelf environments

(3) Anoxic/suboxic mineralization processes, sulfate respiration and $\mathrm{Fe}(\mathrm{III})$ reduction, play a dominant role in oxidizing the $\mathrm{C}$ reaching the sediment surface in at least some cold shelf environments.

(4) Comparison of depth-integrated C oxidation rates from sediment incubations to those measured in situ with a free vehicle benthic lander indicated that the sediment incubation method is not only internally consistent, but it is also fairly accurate.

Acknowledgements. We thank the captain and crew of the RV 'Jan Mayen' for their pleasant, expert assistance. Special thanks to Rick Jahnke for critically reviewing an earlier version of the manuscript and to Philippe Van Cappellen for help with simple modeling. Swantje Fleischer and Kirsten Neumann are acknowledged for their expert, technical assistance. The study was funded entirely by the Max Planck Society. Support from the Skidaway Institute of Oceanography is acknowledged during preparation of the manuscript. The Danish National Science Foundation (SNF) and the Danish National Research Foundation (Denmark's Grundforskningsfond) are acknowledged for their support of D.E.C. We thank 4 anonymous reviewers for their comments which improved the manuscript.

\section{LITERATURE CITED}

Aller RC (1994) The sedimentary Mn cycle in Long Island Sound: its role as intermediate oxidant and the influence of bioturbation, $\mathrm{O}_{2}$ and $\mathrm{C}_{\text {org }}$ flux on diagenetic reaction balances. J Mar Res 52:259-295

Aller RC, Rude PD (1988) Complete oxidation of solid phase sulfides by manganese and bacteria in sediments. Geochim Cosmochim Acta 52:751-765

Aller RC, Mackin JE, Cox RT Jr (1986) Diagenesis of Fe and S in Amazon inner shelf muds: apparent dominance of $\mathrm{Fe}$ reduction and implications for the genesis of ironstones. Cont Shelf Res 6:263-289

Aller RC, Blair NE, Xia Q, Rude PD (1996) Remineralization rates, recycling, and storage of carbon in Amazon shelf sediments. Cont Shelf Res 16:753-786

Anderson LG (1995) Chemical oceanography of the Arctic and its shelf seas. In: Smith WO Jr, Grebmeier JM (eds) Arctic oceanography: marginal ice zones and continental shelves. Coastal and estuarine studies, Vol 49. American Geophysical Union, Washington, DC, p 183-202

Anderson LG, Jones EP (1988) Nutrient regeneration in cold, high salinity bottom water of the Arctic shelves. Cont Shelf Res 8:1345-1355

Andruleit H, Freiwald A, Schafer P (1996) Bioclastic carbonate sediments on the southwestern Svalbard shelf. Mar Geol 134:163-182

Archer D, Devol A (1992) Benthic oxygen fluxes on the Washington shelf and slope: a comparison of in situ microelectrode and chamber flux measurements. Limnol Oceanogr 37:614-629

Barnett PRO, Watson J, Connelly D (1984) A multiple corer for taking virtually undisturbed samples from shelf, bathyal and abyssal sediments. Oceanol Acta 7:399-499

Blackburn TH (1987) Microbial food webs in sediments. In: Sleigh MA (ed) Microbes in the sea. Ellis Harwood, Chichester, p 39-58

Boudreau BP (1994) Is burial velocity a master parameter for bioturbation? Geochim Cosmochim Acta 58:1243-1249

Braman RS, Hendrix SA (1989) Nanogram nitrite and nitrate determination in environmental and biological materials by vanadium(III) reduction with chemiluminescence detection. Anal Chem 61:2715-2718

Burdige DJ, Nealson KH (1986) Chemical and microbiological studies of sulfide-mediated manganese reduction. Geomicrobiol J 4:361-387

Canfield DE (1988) Sulfate reduction and the diagenesis of iron in anoxic marine sediments. PhD thesis, Yale Univ

Canfield DE (1989) Reactive iron in marine sediments. Geochim Cosmochim Acta 53:619-632

Canfield DE, Jørgensen BB, Fossing H, Glud R, Gundersen J, Ramsing NB, Thamdrup B, Hansen JW, Nielsen LP, Hall POJ (1993a) Pathways of organic carbon oxidation in three coastal sediments. Mar Geol 113:27-40

Canfield DE, Thamdrup B, Hansen JW (1993b) The anaerobic 
degradation of organic matter in Danish coastal sediments. Geochim Cosmochim Acta 57:3867-3883

Cline JD (1969) Spectrophotometric determination of hydrogen sulfide in natural waters. Limnol Oceanogr 14:454-458

Devol AH, Christensen JP (1993) Benthic fluxes and nitrogen cycling in the sediments of the continental margin of the eastern North Pacific. J Mar Res 51:345-372

Eilertsen HC, Taasen JP, Weslawski JM (1989) Phytoplankton studies in the fjords of West Spitzbergen: physical environment and production in spring and summer. J Plankton Res 11:1245-1260

Ferdelman TG, Lee $C$, Pantoja S, Harder J, Bebout BM, Fossing $\mathrm{H}$ (1997) Sulfate reduction and methanogenesis in a Thioploca-dominated sediment off the coast of Chile. Geochim Cosmochim Acta 61:3065-3079

Fossing $\mathrm{H}(1995){ }^{35} \mathrm{~S}$-Radiolabeling to probe biogeochemical cycling of sulfur. In: Vairavamurthy MA, Schoonen MAA (eds) ACS Symposium Series, Chap 19. American Chemical Society, Washington, DC, p 348-364

Fossing $\mathrm{H}_{1}$ Jørgensen BB (1989) Measurement of bacterial sulfate reduction in sediments: evaluation of a single-step chromium reduction methods. Biogeochem 8:223-245

Glud RN, Holby O, Hoffman F, Canfield DE (1998) Benthic mineralization and exchange in Arctic sediments (Svalbard). Mar Ecol Prog Ser 173:237-251

Goldberg ED, Koide M (1962) Geochronological studies of deep-sea sediments by the ionium/thorium method. Geochim Cosmochim Acta 26:417-450

Grebmeier JM, McRoy CP (1989) Pelagic-benthic coupling on the shelf of northern Bering and Chukchi Seas. III. Benthic food supply and carbon cycling. Mar Ecol Prog Ser 53: $79-91$

Grebmeier JM, Smith WO Jr, Conover RJ (1995) Biological processes on Arctic continental shelves: ice-ocean-biotic interactions. In: Smith WO Jr, Grebmeier JM (eds) Arctic oceanography: marginal ice zones and continental shelves Coastal and estuarine studies, Vol 49. American Geophysical Union, Washington, DC, p 231-261

Guinasso NL, Schink DR (1975) Quantitative estimates of biological mixing rates in abyssal sediments. J Geophys Res 80:3032-3043

Hall POJ, Aller RC (1992) Rapid, small-volume, flow injection analysis for $\mathrm{CO}_{2}$ and $\mathrm{NH}_{4}{ }^{+}$in marine and freshwaters. Limnol Oceanogr 37:113-119

Henrichs SM, Reeburgh WS (1987) Anaerobic mineralization of marine sediment organic matter: rates and the role of anaerobic processes in the oceanic carbon economy. Geomicrobiol J 5:191-237

Henriksen K, Blackburn TA, Lomstein BA, McRoy CP (1993) Rates of nitrification, distribution of nitrifying bacteria and inorganic $\mathrm{N}$ fluxes in the northern Bering-Chuckchi shelf sediments. Cont Shelf Res 13:629-651

Hines ME, Faganeli J, Planinc R (1997) Sedimentary anaerobic microbial biogeochemistry in the Gulf of Trieste, northern Adriatic Sea: influences of bottom water oxygen depletion. Biogeochemistry 39:65-86

Hulth S, Blackburn TH, Hall POJ (1994) Arctic sediments (Svalbard): consumption and microdistribution of oxygen Mar Chem 46:293-316

Hulth S, Hall POJ, Blackburn TH, Landen A (1996) Arctic sediments (Svalbard): pore water and solid phase distributions of $\mathrm{C}, \mathrm{N}, \mathrm{P}$, and Si. Polar Biol 16:447-462

Jahnke RA, Jackson GA (1992) The spatial distribution of sea floor oxygen consumption in the Atlantic and Pacific Oceans. In: Rowe GT, Pariente $V$ (eds) Deep-sea food chains and the global carbon cyclexy. Kluwer Academic, Amsterdam, p 231-261
Jørgensen BB (1977) The sulfur cycle of a coastal marine sediment (Limfjorden, Denmark). Limnol Oceanogr 5:814-832

Jorgensen BB (1978) A comparison of methods for the quantification of bacterial sulfate reduction in coastal marine sediments. 1. Measurement with radiotracer techniques Geomicrobiol J 1:11-28

Jorgensen BB (1982) Mineralization of organic matter in the sea bed - the role of sulfate reduction. Nature 296:643-645

Kostka JE (1993) Biogeochemical cycling of iron in anoxic environments: the importance of iron speciation and bacterial iron reduction. PhD dissertation, Univ Delaware

Kostka JE, Luther GW III (1994) Partitioning and speciation of solid phase iron in saltmarsh sediments. Geochim Cosmochim Acta 58:1701-1710

Kruse $B$ (1993) Measurement of plankton $\mathrm{O}_{2}$ respiration in gas-tight plastic bags. Mar Ecol Prog Ser 94:155-163

Lord CJ III (1980) The chemistry and cycling of iron, manganese, and sulfur in salt marsh sediments. PhD dissertation, Univ Delaware

Lovley DR (1991) Dissimilatory Fe(III) and Mn(IV) reduction. Microbiol Rev 55:259-287

Lovley DR, Phillips EJP (1986) Availability of ferric iron for microbial reduction in bottom sediments of the freshwater tidal Potomac River. Appl Environ Microbiol 52:751-757

Lustwerk RL, Burdige DJ (1995) Elimination of dissolved sulfide interference in the flow injection determination of $\mathrm{SCO}_{2}$ by addition of molybdate. Limnol Oceanogr 40 : $1011-1012$

Nedwell DB (1.989) Benthic microbial activity in an Anarctic coastal sediment at Signy Island, South Orkney Islands. Estuar Coastal Shelf Sci 28:507-516

Nedwell DB, Walker TR, Ellis-Evans JC, Clarke A (1993) Measurements of seasonal rates and annual budgets of organic carbon fluxes in an Anarctic coastal environment at Signy Island, South Orkney Islands, suggest a broad balance between production and decomposition. Appl Environ Microbiol 59:3989-3995

Nielsen LP (1992) Denitrification in sediment determined from nitrogen isotope pairing. FEMS Microb Ecol 86:357-362

Pfannkuche O, Thiel H (1987) Meiobenthic stocks and benthic acitivity on the NE-Svalbard shelf and in the Nansen Basin. Polar Biol 7:253-266

Pomeroy LR, Deibel D (1986) Temperature regulation of bacterial activity during the spring bloom in Newfoundland coastal waters. Science 233:359-361

Pomeroy LR, Wiebe WJ, Deibel D, Thompson RJ, Rowe GT, Pakulski JD (1991) Bacterial response to temperature and substrate concentration during the Newfoundland spring bloom. Mar Ecol Prog Ser 75:143-159

Postma D (1985) Concentration of $\mathrm{Mn}$ and separation from $\mathrm{Fe}$ in sediments. I. Kinetics and stoichiometry of the reaction between birnessite and dissolved Fe(II) at $10^{\circ} \mathrm{C}$. Geochim Cosmochim Acta 49:1023-1033

Quadfasel DB, Rudels B, Kurz K (1988) Outflow of dense water from a Svalbard fjord into the Fram Strait. Deep-Sea Res 35:1143-1150

Redfield AC (1958) The biological control of chemical factors in the environment. Am Sci 46:1-18

Reigstad M, Wassman P (1996) Importance of advection for pelagic-benthic coupling in north Norwegian fjords. Sarsia 80:245-257

Reimers CE, Jahnke RA, McCorkle DC (1992) Carbon fluxes and burial rates over the continental slope and rise off central California with implications for the global carbon cycle. Global Biogeochem Cycles 6:199-224

Rivkin RB, Anderson MR, Lajzerowicz C (1996) Microbial processes in cold oceans. I. relationship between tempera- 
ture and bacterial growth rate. Aquat Microb Ecol 10: $243-254$

Roden EE, Wetzel RG (1996) Organic carbon oxidation and suppression of methane production by microbial Fe(III) oxide reduction in vegetated and unvegetated freshwater wetland sediments. Limnol Oceanogr 41:1733-1748

Rysgaard S, Finster K, Dahlgaard H (1996) Primary production, nutrient dynamics, and mineralisation in a northeastern Greenland fjord during the summer thaw. Polar Biol 16:497-506

Sahm K, Berninger UG (1998) Abundance, vertical distribution, and community structure of benthic prokaryotes from permanently cold marine sediments (Svalbard, Arctic Ocean). Mar Ecol Prog Ser 165:71-80

Stookey LL (1970) Ferrozine-a new spectrophotometric reagent for iron. Anal Chem 43:779-781

Tabatabi MA (1974) A rapid method for determination of

Editorial responsibility: Otto Kinne (Editor),

Oldendorf/Luhe, Germany sulfate in water samples. Environ Lett 7:237-243

Thamdrup B, Canfield DE (1996) Pathways of carbon oxidation in continental margin sediments of central Chile. Limnol Oceanogr 41:1629-1650

Thamdrup B, Fossing H, Jorgensen BB (1994) Manganese, iron, and sulfur cycling in a coastal marine sediment, Aarhus Bay, Denmark. Geochim Cosmochim Acta 58: $5115-5129$

Van Cappellen P, Gaillard JF, Rabouille C (1993) Biogeochemical transformations in sediments: kinetic models of early diagenesis. In: Wollast R, Mackenzie FT, Chou $\mathrm{L}$ (eds) Interactions of $\mathrm{C}, \mathrm{N}, \mathrm{P}$, and $\mathrm{S}$. Biogeochemical cycles and global change. Springer-Verlag, Barcelona, p 401-445

Wassman P, Andreassen I and others (1996) Pelagic-benthic coupling in the Nordic Seas: the role of episodic events. PSZN I: Mar Ecol 17:447-471

Submitted: June 8, 1998; Accepted: January 12, 1999

Proofs received from author(s): April 6, 1999 